\title{
Analysis of the Implementation of Secondary Education Management on the Marginal Contribution of High/Vocational High Schools in North Sumatra
}

\author{
Yulita Triadiarti ${ }^{1}$, La Ane ${ }^{1}$, Erny Luxy D. Purba ${ }^{1}$, Salsabila Irfan $^{1}$, Dandi Abdul \\ Halim $^{1}$
}

${ }^{1}$ Accounting Department, Universitas Negeri Medan, Indonesia.

* Corresponding Author: yulita@unimed.ac.id

\begin{abstract}
This study analyzes the implementation of education management in senior high/vocational schools in North Sumatra. The research examined the relationship between the implementation of secondary education management and school efficiency as indicated by the marginal contribution of high/vocational high schools in North Sumatra. This study will prove whether there is an effect of implementing secondary education management on the marginal contribution of senior high/vocational schools in North Sumatra. The population in this study were all high school/vocational schools in North Sumatra. Sampling was carried out using Convenience Sampling with mapping sampling based on the number of regencies/cities in North Sumatra. This research is a combination of quantitative and qualitative research. The quantitative method tests the relationship between the variables arranged in the hypothesis using multiple regression analysis. Furthermore, the analysis results were discussed through a Focus Group Discussion with school principals and teachers to determine the formation of the most effective and efficient model in the Implementation of Secondary Education Management in Senior High/Vocational High Schools in North Sumatra. The descriptive qualitative analysis results prove that several implementations of educational standards have been going very well. The implementation of education that still faces several obstacles is the implementation of financing standards, procedures for meeting standards, implementation of standards for the number of educators and education personnel, implementation of quality standards for educators and education personnel, and implementation of standards for students' costs as measured by the fulfilment of students' essential equipment. Graduate Competency Standards, Financing Standards, Educator Quality Standards, Process Standards, Number of Educators Standards, Content Standards, Facilities Standards, Management Standards, Assessment Standards, and Procedures for Standard Compliance simultaneously affect the School's Marginal Contribution.
\end{abstract}

Keywords: Implementation of secondary education management, The marginal contribution of schools

\section{INTRODUCTION}

Changes in education have led to the emergence of a new educational framework. To anticipate this, educational institutions must actively adapt. The activities of educational organizations need to be rethought, and the teacher's job is to find new features that can suit the needs. Currently, educational institutions must develop educational activities in such a way as to be able to meet the changing needs of the state and society. Therefore, educational activities must be built at best. It is crucial to ensure that proper management is carried out. The management model of secondary education activities discussed in this research focuses on a new approach to quality as the main component of quality management, the system's object.

The education quality is measured through the level of effectiveness and efficiency that occurs during 
the implementation of education. The efficiency level can be measured by calculating the school's Marginal Contribution. The marginal contribution is the net income minus the variable costs or direct costs incurred by the school. The use of margin analysis is carried out because it can inform academic planning, enrolment strategies, and school strategic planning. Based on Permendikbud No. 75 of 2016 concerning School Committees, academic units can collect tuition fees from parents/guardians of students based on a clear investment and operation plan as outlined in the strategic plan, annual work plan, and an annual budget that refers to the National Education Standards [8]. In addition, the regulation can collect funds from the community in implementing school management. This is the rationale for measuring the quality of education through management efficiency with the marginal contribution of secondary schools.

Based on the quality analysis, the next step will be to develop a model for managing educational activities. The secondary education activity management model developed is focused on a new approach to quality as a significant component of education management. This model will help improve the management of educational activities in a better direction.

A study researching mapping the quality of School-Based Management in Malang [11]. His research proves that almost $50 \%$ of schools at all levels have not met the minimum educational standards. This means that many schools still need to improve the quality of their education services even though this burden must be added to schools that are still at a minimum standard. Therefore, a good mapping of the quality of education is needed [11].

Research on the relationship between education management and the quality of education has been conducted by Vaganova [12]. According to the study, the authors conclude that a higher education management model developed shows its effectiveness and contributes to improving education management. The higher education management model includes graduate professional characteristics, professional standards, and compliance with educational programs [12].

Research on the relationship between education management and school quality has also been conducted by Nurlaya [6]. In this research, Nurlaya [6] emphasizes the management of education financing. The results showed that education financing management and learning facilities on school quality together gave a solid and significant influence. By $38.5 \%$, education financing and learning facilities management are simultaneously and significantly related to school quality [6]

Based on this background and the research that has been done, the Author is interested in analyzing the implementation of secondary education management in North Sumatra. Therefore, the selection of secondary education, mainly Senior High/Vocational Schools, is considered very appropriate and is in line with Permendikbud No.75 of 2016 concerning the School Committee, which states that schools at the secondary education level can take advantage of funds from the community to manage the implementation of education and the achievement of Minimum Service Standards (SPM). Education.

\section{SCHOOL'S MARGINAL CONTRIBUTION}

The marginal contribution is the remaining amount of revenue minus variable expenses. So this is the amount available to cover fixed expenses and then profit for the period. The contribution margin is used first to cover fixed expenses, and the remainder will be profit. If the contribution margin is not sufficient to cover the company's fixed expenses, there will be a loss for the period. Net profit will increase when the break-even point is reached according to the contribution margin per unit for each additional product sold. Contribution margin is a cost accounting concept that allows a business to determine the profitability of individual products. The contribution margin calculation helps measure the failure or success of a business. Calculating the marginal contribution will also determine what products are added or removed to increase revenue. The choice of reducing variable costs and increasing income is an option in increasing the contribution margin [9].

The marginal contribution of Senior High/Vocational High School is the net income in senior/vocational high school minus the variable costs or direct costs incurred by the school. Margin analysis can be used in various ways to inform academic planning, enrollment strategies, and overall school strategic planning [4].

\section{IMPLEMENTATION OF SECONDARY EDUCATION MANAGEMENT}

In the education development of a nation, it is necessary to have a reliable (effective and efficient) education management system so that it is expected to face very rapid global competition and keep up with 
the development of science and technology (Science). Therefore, the implementation of education management that has met the standards is expected to maintain the quality of education.

Permendikbud No.32 of 2018 has been regulated on the technical standards of minimum education services, which aim to guide local governments in meeting students' basic needs according to the level and path of education. Minimum Education Service Standards, in the future abbreviated as SPM Pendidikan, are provisions regarding the type and quality of essential education services, which are mandatory government affairs that every student has the right to obtain at a minimum. Education MSS is determined and applied based on the principles: suitability of authority, availability, affordability, sustainability, measurability, and targeting accuracy [8]. Essential Service Quality for each Type of Education MSS Basic Service includes:

Educational management is a process and substance dimension in education [10]. As a dimension, process management has been explored in planning, organizing, staffing, directing, budgeting, controlling, evaluating, and reporting. Substantial management includes curriculum, students, teachers, staff, money, facilities, and participation in education management. The organizational level can be analyzed at the global, regional, local, and institutional levels. Organizational functions can be analyzed on leadership, planning, supervision, communication, decision making, and innovation in the management process [2]. Research in educational management has been used for institutional innovation and student achievement.

Research on the implementation of education management has been conducted in Brazil to analyze the contribution of assessment to education management in schools and universities [3]. The research results show different contributions based on the district level assessment scale and a larger scale in the implementation of education management so that different criteria are needed to measure its success.

Anwar [1] has researched educational management standards. The most important essence of educational management standards, especially in the development of private Madrasah Aliyah in Gorontalo City, is the application of educational management standards related to infrastructure support as an element in improving the quality of madrasas. This follows the needs of the community. This factor will be realized if it is maximized through innovation in the educational process and approval of student success, educational institutions that are managed with the principles of independence, partnership, participation, open access, and accountability [1].

\section{METHODS}

In analyzing the data, the Author divides into two stages of analysis

\section{Descriptive qualitative analysis}

Descriptive qualitative analysis was conducted to solve the first and second problems. The analysis was conducted in-depth and descriptive elaboration of the data obtained from distributing questionnaires. The analysis results are strengthened by conducting a group discussion forum involving school principals, teachers, and staff.

\section{The quantitative Method}

The quantitative method is carried out by testing the relationship between the variables arranged in the hypothesis using Multiple Regression Analysis. The research model formed is as follows:

$\mathrm{MC}=\mathrm{a}+\mathrm{b} 1 . \mathrm{SKL}+\mathrm{b} 2 . \mathrm{SI}+\mathrm{b} 3 . \mathrm{SP}+\mathrm{b} 4 . \mathrm{SSP}+$ b5.SPL + b6.SPB + b7.SPN + b8.SJ + b9.SK + b10.TC $+\mathrm{e}$.

Description:

$\mathrm{MC}=$ Marginal Contribution

SKL $=$ Implementation of Graduate Competency Standards

SI = Implementation of Content Standards

$\mathrm{SP}=$ Implementation of Process Standards

$\mathrm{CNS}=$ Implementation of Infrastructure Standards

SPL $=$ Implementation of Management Standards

SPB = Implementation of Financing Standards

NES $=$ Implementation of Assessment Standards

SJ = Implementation of Standard Number of Educators and Education Personnel

SK = Implementation of Quality Standards for Educators and Education Personnel

$\mathrm{TC}=$ Standard Compliance Procedure

\section{RESULTS AND DISCUSSION}

The data used in this research is primary data obtained by distributing questionnaires through Google Form. The respondents of this study were principals and teachers at the schools that were used as 
research samples. The number of respondents was 176 people from high school/vocational schools in all districts and cities in North Sumatra. The data obtained answered the first and second problems through indepth descriptive analysis. Of the 176 respondents' data, only 135 can test the hypothesis using multiple regression analysis after the classical assumption test. Hypothesis testing is done to answer the third and fourth problems. The technique of determining the sample was determined by the convenience sampling method. This method was chosen for ease of obtaining data based on the difficulty of obtaining data from regencies/cities far from the research location.

The implementation of secondary education management in senior high/vocational schools has been regulated in the Minister of Education and Culture Number 32 of 2021 concerning Technical Standards for Minimum Education Services. The indicator based on these regulations is the Quality of Basic Services for each Type of Basic Services Minimum Service Standards (MSS) for Education. Based on these regulations, researchers analyzed using data obtained from respondents.

A descriptive qualitative analysis was carried out on each variable based on the answers obtained from the respondents and strengthened by FGDs that discussed the results of the analysis. The questions in the questionnaire The results of data analysis obtained from respondents are as follows:

Implementation of Graduate Competency Standards (SKL). The results of the answers from respondents showed the following conditions:

1. The chart shows that 113 respondents (64\%) answered in an average interval of $3.36-4$, and 63 people $(36 \%)$ answered in an average interval of 2.43 - 3.05. Based on the categorization, the data are in the good to perfect category. This can prove that $64 \%$ of respondents strongly agree that implementing graduate competency standards has been carried out well in their workplaces. The indicators of graduate competency standards are 1) schools have determined graduate competency qualifications covering knowledge, skills, and attitudes; and 2) graduate competency standards have focused on knowledge to improve learners' competence to live independently and participate in further education. Therefore, it can be concluded that, in general, the implementation of graduate competency standards has been carried out well.

\section{Implementation of Content Standards (SI)}

The results of the analysis on the implementation of the content standards are as follows:
In the chart, it can be seen that about 121 respondents $(68.75 \%)$ answered in an average interval of $3.26-4$, and 55 people $(31.25 \%)$ answered in an average interval of $2.51-3.25$. Therefore, based on the categorization, the data are in the good to perfect category. This can prove that $68.75 \%$ of respondents strongly agree that content standards have been implemented well in their workplaces. The implementation of content standards is carried out based on indicators that schools have: 1) required teachers to conduct curriculum analysis before compiling learning tools; 2) requires teachers to prepare learning tools (RPP, media, worksheets, teaching materials, assessment instruments); and 3) requiring teachers to update educational continually and learning materials according to the specified standards. Therefore, it can be concluded that content standards have been implemented well.

\section{Implementation of Process Standards (SP)}

The results of the analysis on the implementation of the standard process are as follows:

It is known that about 92 respondents $(52.27 \%)$ answered in an average interval of 3.26-4, and 80 people $(45.45 \%)$ answered in an average interval of 2.51-3.25. About four people $(0.02 \%)$ answered at an interval of 1.1-2.50. Based on the categorization, the data is evenly distributed in the good to perfect category and relatively small in the lousy interval. This proves that $52.27 \%$ of respondents strongly agree that process standards have been implemented well in the schools where they work. Implementation of the standard process has been carried out based on indicators that: 1) schools have required every teacher to make lesson plans before carrying out learning activities using varied learning methods; 2) The lesson plans prepared by the teacher have included the formulation of learning outcomes, how to achieve learning objectives and how to assess the achievement of learning objectives; 3) Schools always apply varied methods and appropriate learning strategies to improve student learning outcomes; 4) Schools implement a participatory learning process by conducting many discussion activities to encourage students to think creatively and productively; 5) Assessment of the learning process is carried out by fellow educators (assessment of planning and implementation of learning is carried out by fellow teachers), principals and students. Therefore, it can be concluded that, in general, the implementation of the standard process has been carried out well, as well as some schools have not implemented the standard process. 


\section{Implementation of Infrastructure Standards} (SSP)

The results of the analysis on the implementation of standard facilities and infrastructure are as follows:

The data distribution on the chart shows that about 101 respondents $(57.38 \%)$ answered in an average interval of 3.26-4, and 67 people (38\%) answered in an average interval of 2.51-3.25. About nine people $(0.05 \%)$ answered at an interval of 1.1-2.50. Based on the categorization, the data are in the good to perfect category. Furthermore, relatively small intervals are not reasonable. This can prove that most respondents strongly agree that the standard implementation of facilities and infrastructure has been carried out well. The standard implementation of facilities and infrastructure has been carried out based on indicators that: 1) Schools always identify the needs of their internal customers in terms of facilities and infrastructure; 2) There is sufficient study space to accommodate all students in carrying out learning at the same time; 3) The capacity and condition of the study rooms have met the minimum standards; 4) There is a library equipped with the latest books and a reading room; 5) There are places for exercise, places of worship, laboratories/workshops, playgrounds, places for creation and recreation; and 6) There are facilities for the use of information and communication technology needed to support the learning process. Therefore, it can be concluded that, in general, the standard implementation of facilities and infrastructure has been carried out well. However, some schools still state that school facilities and infrastructure are still inadequate.

5. Implementation of Management Standards (SPL)

The results of the analysis on the implementation of management are as follows:

The chart shows that 96 respondents (54.54\%) answered in an average interval of 3.26-4, and 75 people $(42.61 \%)$ answered in 2.51-3.25. Therefore, based on the categorization, the data are in the good to perfect category. This can prove that most respondents strongly agree that management standards have been implemented well. Furthermore, the implementation of management standards has been carried out based on indicators that: 1) Educational activity planning aims to improve the quality of learning processes and outcomes on an ongoing basis based on school selfevaluation; 2) Planning for Education activities is stated in a short-term (one year) work plan and a medium-term (four year) work plan; 3) The implementation of educational activities is an action to mobilize and use all available resources in schools, in order to achieve goals and objectives under predetermined plans; 4) Supervision of educational activities is periodic and continuous monitoring, supervision, and evaluation activity carried out by the school principal. Therefore, it can be concluded that, in general, the implementation of management standards has been carried out well.

6. Implementation of Financing Standards (SPB)

The results of the analysis on the implementation of financing are as follows:

The chart's respondents' answers show that around 119 people $(67.61 \%)$ answered in an average interval of $3.26-4$, and 39 people $(22.15 \%)$ answered in 2.51 3.25. About 18 people $(10.22 \%)$ answered at an interval of 1.1-2.50. The data is spread from the bad to the perfect category based on the categorization. This can prove that financing standards have not been carried out optimally. The implementation of the measured financing standards is based on the following indicators: 1) Schools analyze the cost of providing education in determining the amount of school tuition; 2) The allocation of BOS funds managed by schools under Permendikbud 8 of 2020 includes 12 main items. It can be concluded that, in general, the implementation of financing standards has been carried out well. However, there are still schools that have not implemented financing policies based on regulations.

7. Implementation of Assessment Standards (SPN)

The results of the analysis on the implementation of the assessment standards are as follows:

The chart shows that 73 respondents $(41.47 \%)$ answered in an average interval of 3.26-4, and 95 people (53.97\%) answered in 2.51-3.25. About eight people (4.54\%) answered at an interval of 1.1-2.50. Based on the categorization, the data are in the poor to perfect category. This proves that several areas have not been carried out assessment standards optimally. Implementation of assessment standards is measured based on the following indicators: 1) Schools already have standards in establishing mechanisms, procedures, and instruments for assessing student learning outcomes; 2) Schools establish formative assessments to monitor and improve the learning process and evaluate the achievement of learning objectives; 3) The school has established a summative assessment to assess the achievement of student learning outcomes as the basis for determining grade promotion and graduation from school; 4) 
Determination of graduation is carried out through a mechanism determined by the school concerning the competency standards of graduates. Based on the results of data analysis from respondents, it can be concluded that, in general, the implementation of assessment standards has not been carried out optimally.

8. Implementation of Students' Basic Equipment Standards

The results of the analysis on the implementation of students' basic equipment standards are as follows:

Based on the distribution of data, it is known that about 58 respondents $(32.95 \%)$ answered in an average interval of $3.26-4$, and 77 people $(43.75 \%)$ answered in an average interval of 2.51-3, 25. About 41 people $(23.29 \%)$ answered at an interval of 1.12.50. Based on the categorization, the data are in the poor to perfect category. It proves that only $32.95 \%$ of respondents strongly agree that students' basic equipment standards have been implemented optimally in their workplaces. The indicators used to measure the standard implementation of students' essential equipment are 1) Schools provide textbooks that are under the curriculum one package/student/year; 2) The school provides learning equipment (tools and notebooks) in new condition 1 set/student/semester. Based on the results of the analysis of the respondents' answers, it can be concluded that the implementation of students' basic equipment standards has not been appropriately implemented. Many schools do not implement these regulations.

9. Implementation of Standard Number of Educators and Education Personnel (SJ)

The results of the analysis on the implementation of the standard number of educators and education personnel are as follows:

That is, about 65 respondents $(36.93 \%)$ answered in an average interval of 3.26-4, and 82 people $(46.59 \%)$ answered in an average interval of 2.513.25. About 29 people $(16.48 \%)$ answered at $1.00-$ 2.50. Based on the categorization, the data are in the poor to perfect category. This proves that only36.93\% of respondents strongly agree that implementing the standard for educators and staff has been implemented optimally.

Implementation of the standard number of educators and staff is carried out based on indicators that: 1) The number of subject teachers is under curriculum needs; 2) the number of laboratory personnel is under what is needed; 3 ) The number of other supporting personnel has been under what is needed. Based on the analysis of respondents' answers, it can be concluded that the standard implementation of the number of educators and staff has not been appropriately implemented. Through in-depth observation, it is known that the unfavorable category's cause is mainly due to the lack of laboratory and supporting staff in schools.

10. Implementation of Standard Number of Educators and Education Personnel (SJ)

The results of the analysis on the implementation of the standard number of educators and education personnel are as follows:

It is known that about 72 respondents $(40.90 \%)$ answered in an average interval of 3.25-4, and 84 people $(47.72 \%)$ answered in an average interval of 2.51-3. 25. About 20 people (11.38\%) answered at $1.00-2.50$. Based on this value, the data distribution is poor to perfect. The data proves that quality standards for educators and staff have not been appropriately implemented. Implementation of quality standards for educators and staff is measured based on the following indicators: 1) Schools always carry out training and guidance to improve the quality of their human resources; 2) All teachers in the school have a D-IV/S1 diploma; 3) All teachers in the school have educator certificates; 4) All teachers in the school have educator certificates; 5) The principal has a D-IV/S1 diploma; 6) The principal has a certificate of completion of education and training for prospective principals; 7) Schools have laboratory personnel who at least have a high school diploma/equivalent; 8) Schools have other supporting staff, at least having a high school diploma/equivalent. Based on in-depth observations made, conditions that indicate the quality standards of educators and staff have not been implemented to the maximum are not all. Teachers have educator certificates, schools do not have adequate laboratory personnel, and there are still principals who do not have a certificate of completion of education and principal training.

11. Implementation of Standard Number of Educators and Education Personnel (SJ)

Hypothesis testing was carried out through a simultaneous significance test ( $\mathrm{F}$ test) on the multiple linear regression equation models. The $\mathrm{F}$ test gives results that will prove whether all independent variables have a joint influence on the dependent variable. The hypothesis is accepted when a significance level of $<5 \%$ or 0.05 .

It can be seen that the calculated F value is 5.596, and the significance value is $0.000<0.05$. Therefore, 
based on the results of this test, it is proven that the Graduate Competency Standards, Financing Standards, Educator Quality Standards, Process Standards, Number of Educators Standards, Content Standards, Facilities Standards, Management Standards, Assessment Standards and Procedures for Standard Compliance, simultaneously affect the School's Marginal Contribution. In other words, with a $5 \%$ confidence level, the data proved that the hypothesis was accepted.

\section{CONCLUSIONS}

Based on observations, discussions, and the results of data analysis, the conclusions that can be drawn from this research are as follows:

1. In general, secondary education management has been carried out well in Senior High/Vocational Schools in North Sumatra. Based on the descriptive qualitative analysis results, it proves that there are several implementations of educational standards that have been going very well in high/vocational high schools in the province of North Sumatra. The implementation that has gone very well is the graduate quality standard $(64 \%)$, content standard $(68.75 \%)$, process standard $(52.27 \%)$, facilities and infrastructure standard $(57.38 \%)$, management standard $(54,54 \%)$. In addition, several standards have not been implemented very well in some areas. The implementation of education implementation that still faces several obstacles is the implementation of financing standards (10.22\% stated that it was not implemented well), assessment standards $(4.54 \%$ stated that it had not been implemented), and procedures for meeting standards $(7.96 \%$ stated that it had not been implemented). In addition, several standard implementations have more special attention because a relatively large percentage of statements have not been appropriately implemented. The implementations are: the implementation of the standard for the number of educators and education staff $(16.48 \%$ said it had not been implemented well), the implementation of the quality standard for educators and education personnel (11.38\% said it had not been implemented well), and the last one was the implementation of the private cost standard. As measured by the fulfillment of students' essential equipment $(23.28 \%)$, students stated that it was not implemented).
2. The leading causes of not implementing the education standards are as follows:

a. Funding standards: Many schools have not analyzed the cost of providing education in determining the amount of school tuition fees. Based on the Regulation of the Minister of Education and Culture Number 32 of 2021 concerning Technical Standards for Minimum Education Services, the analysis of the cost of providing education is the primary standard to manage the efficient implementation of education.

b. The standard number of educators and education personnel: although in relatively small numbers, there are still in some areas the number of subject teachers under the curriculum is not sufficient, the number of laboratory personnel is not sufficient as needed, and the number of supporting staff is not sufficient as needed.

c. Quality standards of educators and education personnel: based on data, the leading cause of the low value of implementing this standard is that there are still many teachers in schools who do not yet have an educator certificate, and there are still principals who do not have a certificate of completion of education and training for prospective principals.

d. The standard of students' costs as measured by the fulfillment of students' essential equipment: based on data analysis, relatively low implementation is in the implementation of providing learning equipment (tools and notebooks) in a new condition of $1 \mathrm{set} /$ student/semester, especially in public schools.

3. The implementation of secondary education management has been shown to affect school efficiency, indicated by the marginal contribution of Senior High/Vocational Schools in North Sumatra. This is evidenced by testing the multiple linear regression analysis equation model which produces the equation model $\mathrm{MC}=-4.637-0.084$ $\mathrm{SKL}+0.187 \mathrm{SI}+0.437 \mathrm{SP}+0.119 \mathrm{SSP}-0.382$ $\mathrm{SPL}+0.026 \mathrm{SPB}+0.444 \mathrm{SPN}+0.722 \mathrm{SJ}-0.751$ $\mathrm{SK}+0.554 \mathrm{TC}$. Using the F test, the calculated F value is 5.596, and the significance value is 0.000 $<0.05$. Based on the results of this test, it is proven that the Graduate Competency Standards, Financing Standards, Educator Quality Standards, Process Standards, Number of Educators Standards, Content Standards, Facilities Standards, Management Standards, Assessment Standards and Procedures for Standard Compliance, simultaneously affect the School's Marginal Contribution. In other words, with a 5\% 
confidence level, the data proved that the hypothesis was accepted.

\section{REFERENCES}

[1] Anwar, H., Implementation of Education Management Standard in The Guidance of Private Islamic High School. Jurnal Pendidikan Islam, $4(1)$, 2018. https://doi.org/10.15575/jpi.v4i1.2250

[2] Barbón Pérez, O. G., \& Fernández Pino, J. W. The role of strategic educational management in knowledge management, science, technology, and innovation in higher education. Educacion Medica, 19(1), 2018. https://doi.org/10.1016/j.edumed.2016.12.001

[3] Bauer, A., Assessment of educational systems and educational management: Theoretical contributions. Educacao and Realidade, 44(1), 2019. https://doi.org/10.1590/2175-623677006

[4] Diris, R., \& Ooghe, E., The economics of financing higher education. Economic Policy, 33(94).

2018. https://doi.org/10.1093/epolic/eiy003

[5] Field, A., Discovering statistics using IBM SPSS statistics. In Statistics (Vol. 58). 2013.

[6] Nurlaya, I L., PENGARUH MANAJEMEN PEMBIAYAAN PENDIDIKAN DAN FASILITAS PEMBELAJARAN TERHADAP MUTU SEKOLAH. Al-Hasanah: Islamic Religious Education Journal, 5(2), 2020. https://doi.org/10.51729/525

[7] Pendidikan, M., Kebudayaan, D. A. N., \& Indonesia, R., Peraturan Menteri Pendidikan Dan Kebudayaan Republik Indonesia Nomor 32 Tahun 2018 Tentang Standar Teknis Pelayanan Minimal Pendidikan. 2018.

[8] Permendikbud, N. 75 T., Tentang Dewan pendidikan Dan Komite Sekolah. Journal of Chemical Information and Modeling, 53(9), 2016, pp 1-11.

[9] Psacharopoulos, G., Measuring the Marginal Contribution of Education to Economic Growth. Economic Development and Cultural Change, 20(4), 1972, https://doi.org/10.1086/450586

[10] Pulido Capurro, V., \& Olivera Carhuaz, E., Educational management: An entrepreneurial vision of basic education. Revista Científica de La UCSA, 6(3), 2019. https://doi.org/10.18004/ucsa/24098752/2019.006.03.052-062

[11] Triwiyanto, T., Pemetaan mutu manajemen berbasis sekolah melalui audit manajemen pendidikan. Jurnal Manajemen Pendidikan, 24(2), 2013, pp 125-134. http://ap.fip.um.ac.id/wpcontent/uploads/2015/05/volume-24-no.-23443.pdf

[12] Vaganova, O. I., Gilyazova, O. S., Gileva, A. V., Yarygina, N. A., \& Bekirova, E. S., Quality management of educational activities in higher education. Revista Amazonia Investiga, 9(28), 2020, $\mathrm{pp}$ 74-82. https://doi.org/10.34069/ai/2020.28.04.9 